\title{
Pronucleus formation in bovine oocytes activated by a single electric pulse
}

\author{
E Běhalová 1, SD Smith 2, P Hyttel 3, T Greve 2* \\ ${ }^{1}$ Institute of Animal Physiology and Genetics, Czech Academy of Sciences, \\ 27721 Libèchov, Czech Republic; \\ ${ }^{2}$ Department of Clinical Studies, Reproduction; \\ ${ }^{3}$ Department of Anatomy and Physiology, The Royal Veterinary and Agricultural University, \\ Bülowsvej 13, 1870 Frederiksberg C,Denmark
}

(5th Franco-Czechoslovak Meeting, Jouy-en-Josas, December 1992)

\begin{abstract}
Summary - Bovine oocytes matured in vitro were stimulated by a single pulse of direct current (DC), then cultured for $0.5-6 \mathrm{~h}$ and evaluated by light (LM) and transmission electron microscopy (TEM). At the light microscopic level, the beginning of oocyte chromatin decondensation was first observed $3 \mathrm{~h}$ post-activation (14\%). A well-developed pronucleus with evenly granulated nucleoplasm surrounded by nuclear membrane was found in 12,61 and $81 \%$ oocytes at 4,5 and $6 \mathrm{~h}$ postactivation, respectively. The TEM evaluation revealed that nuclear membrane vesicules were first visible at $0.5 \mathrm{~h}$ post-activation and became even more prominent at $1 \mathrm{~h}$. Based on these observations, it is concluded that a nuclear membrane starts to form immediately after oocyte activation, while a well-developed pronucleus appears at 4-6 $\mathrm{h}$.
\end{abstract}

oocyte / activation / nuclear envelope / pronucleus / bovine species

Résumé - Formation du pronoyau dans les ovocytes bovins activés par un choc électrique unique. Des ovocytes bovins maturés in vitro ont été stimulés par un seul choc électrique (courant continu), cultivés de 0,5 à $6 \mathrm{~h}$ et observés en microscopie optique et électronique à transmission (MET). Au microscope photonique, le début de la décondensation de la chromatine est observable $3 \mathrm{~h}$ après l'activation (14\%). Un pronoyau bien développé avec un nucléoplasme régulièrement granulaire, entouré d'une membrane, est retrouvé dans 12, 61 et $81 \%$ des ovocytes, 4,5 et $6 \mathrm{~h}$ après activation. La MET révèle que les vésicules formant l'enveloppe nucléaire apparaissent une demiheure après activation et deviennent plus évidentes après $1 \mathrm{~h}$. D'après ces observations, on peut conclure qu'une enveloppe nucléaire commence à se former immédiatement après l'activation de l'ovocyte tandis qu'un pronoyau bien formé n'apparaît qu'après 4 à $6 \mathrm{~h}$.

ovocyte / activation / enveloppe nucléaire / pronoyau / espèce bovine

${ }^{*}$ Correspondence and reprints 


\section{INTRODUCTION}

In most mammalian species, the ovulated eggs are arrested at the metaphase of the second meiotic division until sperm-egg fusion. The sperm activation stimulus can be simulated artificially, ie parthenogenetically, via, for example by $\mathrm{Ca}^{2+}$ ionophore A23187 (Ware et al, 1989), protein synthesis inhibitors (First et al, 1992) or ethanol (Nagai, 1987) and also by an electric pulse. It has been demonstrated that electrically activated oocytes exhibit similar characteristics to penetrated eggs: establishment of zona pellucida block prevents polyspermic penetration (Gwatkin et al, 1973; Běhalová et al, 1992), completion of meiosis, chromatin decondensation and pronuclear formation (Landa and Hájková, 1989; Procházka et al, 1992), cleavage (Tarkowski et al, 1970; Kaufman et al, 1975; Prather et al, 1991; Procházka et al, 1993) and in particular cases limited postimplantation development (Ozil, 1990). Although the kinetics of pronucleus formation in activated bovine oocytes has been monitored (Landa and Hájková, 1989; Powell and Barnes, 1992), to our knowledge, no reports exist on nuclear envelope development prior to chromatin decondensation. Reaching a better understanding of pronucleus formation will be useful, especially in nuclear transfer experiments.

The present study was therefore conducted to determine pronucleus formation in electrically activated, in vitro matured bovine oocytes. The light microscopic (LM) observations were accompanied by transmission electron microscopy (TEM) to evaluate the immediate ultrastructural changes in relation to nuclear membrane development.

\section{MATERIALS AND METHODS}

\section{Oocyte recovery and culture}

Bovine ovaries, collected at a slaughterhouse, were kept in phosphate-buftered saline (PBS) at $33^{\circ} \mathrm{C}$ and transported to the laboratory within 1$3 \mathrm{~h}$ slaughter. Oocytes were obtained by aspiration from antral follicles (4-8 $\mathrm{mm}$ in diameter) and only the cumulus-oocyte complexes (COC) with tightly compacted multi-layers of cumulus cells were selected for culture (Xu et al, 1986). About $20 \mathrm{COC}$ were placed in $0.5 \mathrm{ml}$ medium under paraffin oil and cultured at $39^{\circ} \mathrm{C}$ in an atmosphere of $5 \% \mathrm{CO}_{2}, 10 \% \mathrm{O}_{2}$ and $85 \% \mathrm{~N}_{2}$ for $28 \mathrm{~h}$. The culture medium was composed of modified M-199 (Pavlok et al, 1992) supplemented with $20 \%$ heat-inactivated estrous cow serum (ECS) and $20 \mathrm{IU}$ per $\mathrm{ml} \mathrm{PMSG/HCG} \mathrm{(Suigonan,}$ Intervet, 2720 Skovlunde, Denmark). Following the maturation period, $\mathrm{COC}$ were stripped of their cumulus cells by vortexing in $0.1 \%$ hyaluronidase for $2 \mathrm{~min}$ and washed several times in TCM-199 supplemented with $10 \%$ ECS. The denuded oocytes were evaluated under a stereomicroscope and only those with spherical shape, a visible first polar body and evenly granulated ooplasm were selected for activation.

\section{Oocyte activation}

Due to the necessary time required for denudation and selection, all oocytes were pulsed at $\approx 30 \mathrm{~h}$ after the onset of culture. Prior to pulse treatment oocytes were equilibrated for $2 \mathrm{~min}$ in electroporation medium (Willadsen, 1986) and then placed in a fusion chamber consisting of 2 parallel wire electrodes $0.5 \mu \mathrm{m}$ apart. The chamber was connected to a Krüss CFA 400 electrofusion apparatus and overlaid with electroporation medium. Activation was electrically induced using a field of alternating current $(A C)$ of $6 \mathrm{~V}$ and $600 \mathrm{kHz}$ for oocytes alignment and a single $1,1.125$ or $1.25 \mathrm{kV} / \mathrm{cm}$ DC pulse of $30 \mu \mathrm{s}$ duration. After stimulation the oocytes were washed 
through $\mathrm{M}-199+10 \%$ ECS and cultured in the same medium under the previously described culture conditions for $0,0.5$ and $1 \mathrm{~h}$ (TEM) or for $0.5,1,2,3,4,5,6$ and $24 \mathrm{~h}$ (LM). Control unpulsed oocytes were cultured for an additional $1 \mathrm{~h}$ (TEM) or $24 \mathrm{~h}$ (LM).

\section{Oocyte examination}

At the end of each culture period, oocytes were processed for LM or TEM (see later). Oocytes for LM were mounted on slides, fixed in acetic ethanol (1:3) for $24 \mathrm{~h}$, stained with $1 \%$ acetic orcein and differentiated in $25 \%$ acetic acid. Oocytes which had progressed to anaphase II; pronucleus (PN) formation or cleavage were considered activated. For the description of karyokinesis within $6 \mathrm{~h}$ post-activation, the modified criteria of $\mathrm{Xu}$ and Greve (1988) were adopted. Briefly, PN1 was substituted by anaphase II (AII) and telophase II (TII), oocytes with the second polar body abstricted were classified as PN2 and those with initial chromosome decondensation and nuclear envelope formation as PN3. Oocytes showing complete chromosome decondensation and pronucleus surrounded by nuclear membrane were classified as category PN4 . Oocytes which possessed 2 polar bodies and chromosomes arranged in a metaphase plate were termed as being in the third meiotic metaphase (MIII) (Kubiak, 1989).

Oocytes for TEM were fixed at $0 \mathrm{~h}(n=3)$, $0.5 \mathrm{~h}(n=4)$ and $1 \mathrm{~h}(n=5)$ after stimulation and control oocytes $(n=3)$ after $1 \mathrm{~h}$ of additional culture and processed according to Hyttel and Madsen (1987). Briefly, specimens were fixed in $3 \%$ glutaraldehyde in $0.1 \mathrm{M}$ phosphate buffer for $1 \mathrm{~h}$ at $4^{\circ} \mathrm{C}$, washed twice in $0.1 \mathrm{M}$ phosphate buffer, post-fixed in $1 \% \mathrm{OsO}_{4}$ in $0.1 \mathrm{M}$ phosphate buffer, washed twice in distilled water, uranyl block-stained, dehydrated and embedded in Epon. Subsequently, semi-thin sections were prepared and stained with $1 \%$ basic toluidine blue for LM evaluation. Selected sections were reembedded; ultrathin sections were contrasted for TEM.

\section{Statistics}

The data were compared by $\chi^{2}$ analysis at $p=$ 0.05 .

\section{RESULTS}

\section{Experiment 1}

The extent of activation caused by handling and denuding of in vitro matured oocytes was examined in experiment 1.

At the end of maturation period, 2 groups of oocytes, ie COC versus denuded, were cultured for an additional $24 \mathrm{~h}$ and after fixation scored for activation. As seen from table I, activation rate in denuded oocytes $(13 \%)$ was not significantly higher than the COC group (3\%) $(p>$ $0.05)$. Cytologically, the majority of activated eggs (7/11) exhibited formation of a third metaphase.

\section{Experiment 2}

Experiment 2 assessed the optimal level of an electrical DC pulse for oocyte activation (table II). The exposure to a single DC pulse of $1,1.125$ and $1.25 \mathrm{kV} / \mathrm{cm}$ caused activation of $73-79 \%$ oocytes fixed $24 \mathrm{~h}$ after stimulation. Although the activation rate was similar $(p>0.05)$ at all pulses used, the stronger stimulations (1.125 and 1.25 $\mathrm{kV} / \mathrm{cm}$ ) increased the number of degenerated oocytes $(9-10 \%$ compared to $0 \%$ at 1 $\mathrm{kV} / \mathrm{cm}$ ) and negatively affected the extru-

Table I. Effect of handling on spontaneous activation in cumulus oocyte complexes (COC) and denuded bovine oocytes (total of 5 replicates per group).

$\begin{gathered}\text { Type } \\ \text { of } \\ \text { oocyte }\end{gathered}$
Total Activated (\%)

$\begin{array}{llllll}\text { COC } & 69 & 2(3) & & 1 & 1 \\ \text { Denuded } & 72 & 9(13) & 7 & 2 & \end{array}$


Table II. The activation of bovine oocytes at different parameters of DC pulse (total of 4-5 replicates per group).

\begin{tabular}{llll}
$\begin{array}{c}\text { Pulse } \\
\text { strength } \\
(k V / c m)\end{array}$ & \multicolumn{3}{c}{ No of oocytes } \\
\cline { 2 - 4 } & Pulsed & $\begin{array}{c}\text { Activated } \\
(\%)\end{array}$ & $\begin{array}{c}\text { Degenerated } \\
(\%)\end{array}$ \\
\hline & & & \\
1.00 & 98 & $74(76)$ & $0^{\mathrm{a}}$ \\
1.125 & 67 & $49(73)$ & $\begin{array}{l}7(10)^{\mathrm{b}} \\
1.25\end{array}$ \\
& 67 & $53(79)$ & $6(9)^{\mathrm{b}}$ \\
Control & 107 & $10(9)$ & 0 \\
\hline
\end{tabular}

a,b Values with different superscripts are statistically different $(p<0.05)$.

sion of the second polar body (45-51\% compared to $26 \%$ at $1 \mathrm{kV} / \mathrm{cm}$; data not shown). Based on these results, a single DC pulse of $1 \mathrm{kV} / \mathrm{cm}$ was chosen for oocyte activation in the following experiments.

\section{Experiment 3}

Experiment 3 described the sequence of pronucleus formation in parthenogenetically stimulated oocytes during the first $6 \mathrm{~h}$ post-activation. As shown in table III, All was reached within $0.5 \mathrm{~h}(88 / 88,100 \%)$ and TIl within $1 \mathrm{~h}(90 / 90100 \%)$ postactivation. The majority of the pulsed oocytes $(66 / 83,80 \%)$ extruded the second polar body (PN2) within $2 \mathrm{~h}$ post- stimulation. The initial decondensation of the chromatin (PN3) was first observed at $3 \mathrm{~h}$ post-activation $(13 / 96,14 \%)$. The welldeveloped pronucleus with an evenly granulated nucleoplasm, surrounded by nuclear membrane (PN4) was seen in oocytes at $4 \mathrm{~h}(11 / 94,12 \%)$ post-activation and increased in frequency at 5 and $6 \mathrm{~h}(60 / 98$, $61 \%$ and $64 / 79,81 \%$, respectively).

\section{Experiment 4}

Immediate ultrastructural changes in activated oocytes were evaluated in experiment 4 . From the oocytes fixed at 0.5 and $1 \mathrm{~h}$ post-stimulation, 7 were activated: 4 in All and 3 in TII. TEM observation showed that portions of nuclear envelope developing from the smooth endoplasmatic reticulum were visible at $0.5 \mathrm{~h}$ post-activation (fig 2) and became even more prominent at $1 \mathrm{~h}$ (fig $3 \mathrm{~b}$ ). The nuclear envelope portions were always found at that side of the chromatin, which faced the center of the ovum, leaving space for peripheral attachment of microtubules. All unpulsed oocytes fixed after $1 \mathrm{~h}$ were at MII.

\section{DISCUSSION}

Parthenogenetic activation of mammalian oocytes was induced by several physical and chemical stimuli. It cannot be excluded that the oocytes may be exposed to one or more of these stimuli during their in vitro handling procedures. Graham (1970) and

Fig 1. Detail of an oocyte fixed immediately after electric stimulation with the arrangement of the chromatin (C) in metaphase configuration with microtubules (arrows) attached. Note the location of vesicules $(\mathrm{V})$ at the poles of the spindle. $\mathrm{ZP}$ : zona pellucida ; bar $=2 \mu \mathrm{m}$.

Fig 2. Detail of an oocyte fixed 30 min after electric stimulation with the chromatin (C) arranged in the anaphase configuration. Note the initial formation of nuclear envelope portions (NE) from the smooth endoplasmic reticulum (SER). Pvs : perivitelline space ; bar $=1 \mu \mathrm{m}$. 

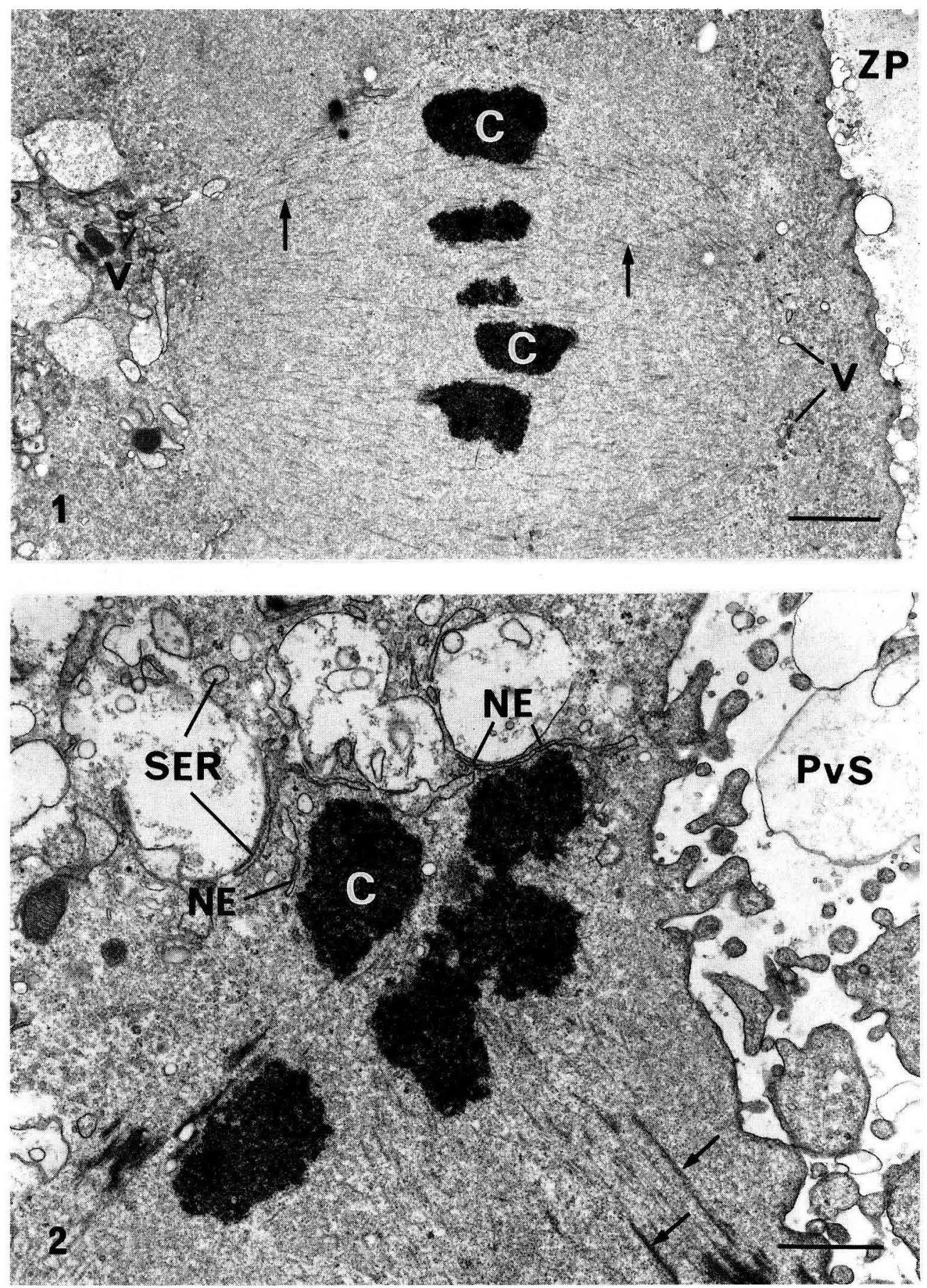
Table III. Chronology of pronucleus formation within $6 \mathrm{~h}$ post-activation (total of $4-5$ replicates per group).

\begin{tabular}{|c|c|c|c|c|c|c|c|c|c|}
\hline \multirow{2}{*}{$\begin{array}{l}\text { Culture } \\
\text { period } \\
\text { (h) }\end{array}$} & \multicolumn{3}{|c|}{ No of oocytes } & \multicolumn{6}{|c|}{ Developmental stage of activation } \\
\hline & Pulsed & Degenerated & Activated & MIII & All & $T \prime \prime$ & PN2 & PN3 & PN4 \\
\hline 0.5 & 99 & 0 & 88 & & 40 & 42 & 6 & & \\
\hline 1 & 102 & 3 & 90 & & & 37 & 53 & & \\
\hline 2 & 102 & 4 & 83 & & & 17 & 66 & & \\
\hline 3 & 104 & 3 & 96 & & & 2 & 81 & 13 & \\
\hline 4 & 105 & 2 & 94 & 4 & & 1 & 45 & 33 & 11 \\
\hline 5 & 104 & 1 & 98 & 4 & & 1 & 14 & 19 & 60 \\
\hline 6 & 86 & 5 & 79 & 7 & & & 1 & 7 & 64 \\
\hline Total & 702 & $18(3)^{\star}$ & $628(89)$ * & & & & & & \\
\hline
\end{tabular}

* in \% from pulsed oocytes.

Kaufman (1973) observed parthenogenetic activation of mouse oocytes by exposure to hyaluronidase. On the other hand, hyaluronidase did not appear to activate in vivo (King et al, 1988) and in vitro (Procházka et al, 1993) matured bovine oocytes. This is confirmed by the present data where handling and denudation did not result in a significant increase in activation rate compared to the $\mathrm{COC}$ group.

Studies of the kinetics of bovine sperm penetration in vitro have shown that the first ova with sperm heads in the ooplasm appeared between 3-6 $\mathrm{h}$ postinsemination and their number increased until 5-16 h (Xu and Greve, 1988; Park et al, 1989; Cox, 1991; Saeki et al, 1991). Since the oocytes used for IVF by the above authors were cultured for 24-27 h before insemination, the oocyte spermatic activation occurred between $27-30 \mathrm{~h}$ after onset of oocyte maturation culture. It has been demonstrated that the response of bovine oocytes to parthenogenetic stimuli generally increased with their ageing and reached a maximum at 30-32 h (Nagai, 1987; Ware et al, 1989; Procházka et al, 1993). Moreover, development of zygotes from oocytes matured for 26-28 h led to $45-60 \%$ of blastocysts (Běhalová and Avery, unpublished results). It was therefore decided to culture oocytes for $28 \mathrm{~h}$ and taking into account the necessary time for denudation and selection, oocytes were pulsed at $\approx 30 \mathrm{~h}$.

Enhanced oocyte activation by numerous pulses has already been established (Kono et al, 1989; Collas and Barnes, 1992; Procházka et al, 1993). However, under our optimal conditions, a single electric stimulus led to $76-89 \%$ of oocytes activation. Compared to the data obtained by

Fig 3. a. Detail of an oocyte fixed $60 \mathrm{~min}$ after electric stimulation with the chromatin (C) at the anaphase configuration. Note the prominent midbody $(\mathrm{Mb})$ at the attachment to the developing second polar body (PB); bar: $2 \mu \mathrm{m}$. b. Detail of the same oocyte as in a. Note the chromatin (C) with the attached microtubules (arrows) and the development of large portions of nuclear envelope (NE) from the smooth endoplasmatic reticulum (SER); bar: $1 \mu \mathrm{m}$. 

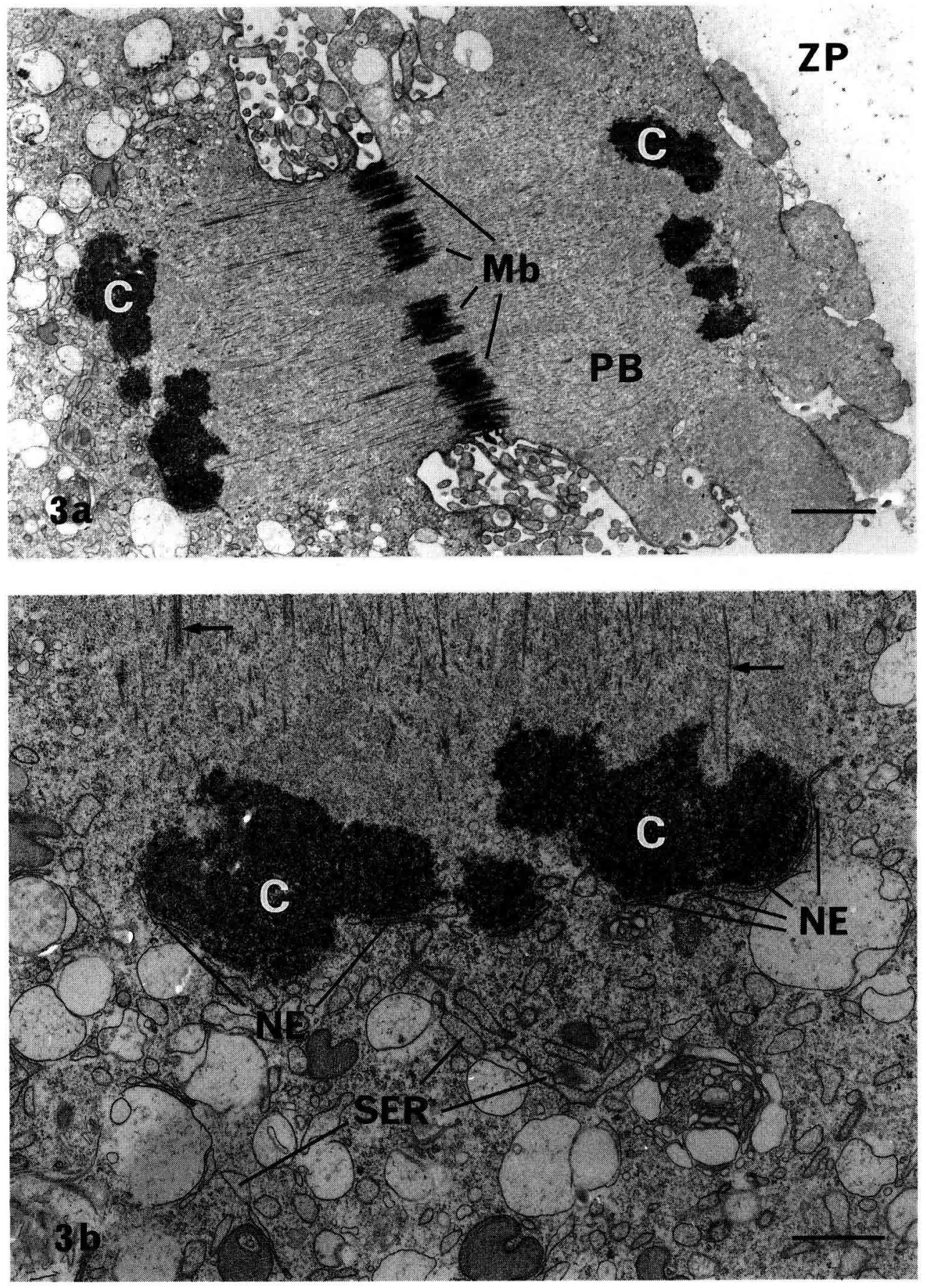
Kono et al (1989), Collas and Barnes (1992) and Procházka et al (1993), a single electric pulse was just as effective as multiple stimulations. The principal benefit of the repetitive stimulation was probably caused by the intervals between successive pulses, which allowed further oocyte cytoplasmic maturation (Procházka et al, 1993).

The time sequence of pronucleus formation was similar to other reports of parthenogenetically stimulated oocytes (Landa and Hájková, 1989; Powell and Barnes, 1992) and in vitro fertilized zygotes (Xu and Greve, 1988). Although the second polar body extrusion was completed within the first $2 \mathrm{~h}$ of activation by pulse or gamete fusion, the onset of chromatin decondensation differed according to oocyte age. In ageing eggs ( $\mathrm{Xu}$ and Greve, 1988; Powell and Barnes, 1992) chromatin decondensation and nuclear membrane formation was noted earlier, at $2 \mathrm{~h}$ compared to $3 \mathrm{~h}$ post-activation as observed by Landa and Hájková (1989) and the present study. The faster nucleus formation in aged oocytes was probably due to a low level of maturation-promoting factor (MPF) activity known to be responsible for nuclear envelope breakdown, chromosome condensation and spindle formation (Masui and Markert, 1971). This asynchrony became indistinguishable at $6 \mathrm{~h}$ post-activation when most of oocytes or zygotes possessed a well-developed pronucleus (Xu and Greve, 1988; Landa and Hájková, 1989; Powell and Barnes, 1992; and the present results).

At the ultrastructural level, the association of the maternal chromosomes with segments of the nuclear envelope was initiated within the first $4 \mathrm{~h}$ of ovulation in vivo and chromatin decondensation as well as nucleus envelope formation were complete at 5-7 h (Hyttel et al, 1988). This time-sequence contrasts with the present results in which nuclear membrane vesicles were already visible by TEM at $0.5 \mathrm{~h}$ post-activation and chromatin decondensation by LM occurred at $3 \mathrm{~h}$. This discrepancy may be due to the delay caused by sperm-egg binding and penetration of the zona pellucida under the in vivo fertilization situation. In other mammalian species such as in parthenogenetically stimulated mouse, hamster and rabbit oocytes, no onset of pronucleus formation was observed by TEM within the first $h$ post-activation (Gulyas, 1976).

In conclusion, the present study described the time sequence of pronucleus formation in parthenogenetically activated in vitro matured bovine oocytes. It was established that the nuclear membrane starts to form immediately after oocyte activation, and that a well-developed pronucleus appears at $4-6 \mathrm{~h}$.

\section{ACKNOWLEDGMENTS}

The authors are indebted to J Fulka, J Motlik and $\mathrm{R}$ Procházka for their critical comments during the preparation of the manuscript, JE Fléchon for translation of the French summary, and to I Heinze and $J$ Nielsen for their skilful technical assistance. E Běhalová would like to thank the staff of the Department of Clinical Studies, Reproduction, RVA, Denmark for helpful cooperation and excellent working possibilities during her fellowship. This work was supported by The Animal Biotechnology Research Centre and The Danish Agricultural and Veterinary Research Council.

\section{REFERENCES}

Běhalová E, Hyttel P, Smith SD, Greve T, Callesen $H$ (1992) The block against polyspermic fertilization in cattle. Micron Microsc Acta 23, 69-70

Collas P, Barnes FL (1992) Parthenogenetic development of bovine oocytes. Biol Reprod 46 (suppl 1), 65

Cox JF (1991) Effect of the cumulus on in vitro fertilization of in vitro matured cow and sheep oocytes. Theriogenology 35,191 
First NL, Leibfried-Rutledge ML, Northey DL, Nuttleman PR (1992) Use of in vitro matured oocytes $24 \mathrm{~h}$ of age in bovine nuclear transfer. Theriogenology 37,211

Graham CF (1970) Parthenogenetic mouse blastocysts. Nature (Lond) 266, 165-167

Gulyas BL (1976) Ultrastructural observations on rabbit, hamster and mouse eggs following electrical stimulation in vitro. Am J Anat 147, 203-218

Gwatkin RBL, Williams DT, Hartmann JF, Kniazuk M (1973) The zona reaction of hamster and mouse eggs: production in vitro by a trypsin-like protease from cortical granules. $J$ Reprod Fertil 32, 259-265

Hyttel P, Madsen I (1987) Rapid method to prepare mammalian oocytes and embryos for transmission electron microscopy. Acta Anat 129, 12-14

Hyttel P, Greve T, Callesen H (1988) Ultrastructure of in vivo fertilization in superovulated cattle. J Reprod Fertil 82, 1-13

Kaufman MH (1973) Parthenogenesis in the mouse. Nature (Lond) 242, 475-476

Kaufman MH, Huberman E, Sachs L (1975) Genetic control of haploid parthenogenetic development in mammalian embryos. Nature (Lond) 254, 694-695

King WA, Xu KP, Sirard MA, Greve T, Leclerc $P$, Lambert RD, Jacques $P$ (1988) Cytogenetic study of parthenogenetically activated bovine oocytes matured in vivo and in vitro. Gamete Res 20, 265-274

Kono T, Iwasaki S, Nakahara T (1989) Parthenogenetic activation by electric stimulus of bovine oocytes matured in vitro. Theriogenology $32,569-576$

Kubiak JZ (1989) Mouse oocytes gradually develop the capacity for activation during the metaphase II arrest. Dev Biol 136, 537-545

Landa V, Hájková M (1989) Parthenogenetic activation of cattle oocytes by a single pulse of direct current. Folia Biol (Prague) 35, $307-$ 313

Masui Y, Markert CL (1971) Cytoplasmic control of nuclear behavior during meiotic maturation of frog oocytes. J Exp Zool 177, 129-145

Nagai $T$ (1987) Parthenogenetic activation of cattle follicular oocytes in vitro with ethanol Gamete Res 16, 243-249
Ozil JP (1990) The parthenogenetic development of rabbit oocytes after repetitive pulsatile electrical stimulation. Development 109 , 117-127

Park CK, Ongoda O, Niwa K (1989) Penetration of bovine follicular oocytes by frozen-thawed spermatozoa in the presence of caffeine and heparin. J Reprod Fertil 86, 577-582

Pavlok A, Lucas-Hahn A, Niemann H (1992) Fertilization and developmental competence of bovine oocytes derived from different categories of antral follicles. Mol Reprod Dev 31, 63-67

Powell R, Barnes FL (1992) The kinetics of oocyte activation and polar body formation in bovine embryo clones. Mol Reprod Dev 33, 53-58

Prather RS, Eichen PA, Nicks DK, Peters MS (1991) Artificial activation of porcine oocytes matured in vitro. Mol Reprod Dev 28, 405409

Procházka R, Kaňka J, Š Sutovský P, Fulka J, Motlík J (1992) Development of pronuclei in pig oocytes activated by a single electric pulse. J Reprod Fertil 96, 725-734

Procházka R, Durnford R, Fiser PS, Marcus GJ (1993) Parthenogenetic development of activated in vitro matured bovine oocytes. Theriogenology 39, 1025-1032

Saeki K, Kato H, Hosoi Y, Miyake M, Utsumi K, Iritani A (1991) Early morphological events of in vitro fertilized bovine oocytes with frozenthawed spermatozoa. Theriogenology 35 , 1051-1058

Xu KP, Greve T, Smith SD, Hyttel P (1986) Chronological changes of bovine follicular oocyle maturation in vitro. Acta Vet Scand 27, 505-519

Xu KP, Greve T (1988) A detailed analysis of early events during in vitro fertilization of bovine follicular oocytes. J Reprod Fertil 82, 127-134

Tarkowski AK, Witkowska A, Nowicka J (1970) Experimental parthenogenesis in the mouse. Nature (Lond) 226, 162-165

Ware CB, Barnes FL, Maiki-Laurila M, First NL (1989) Age dependence of bovine oocyte activation. Gamete Res 22, 265-275

Willadsen SM (1986) Nuclear transplantation in sheep embryos. Nature (Lond) 320, 63-65 